\title{
ARTICLE \\ The Role of the Library in the Digital Economy
}

Serhii Zharinov

\section{ABSTRACT}

The gradual transition to a digital economy requires all business entities to adapt to the new environmental conditions that are taking place through their digital transformation. These tasks are especially relevant for scientific libraries, as digital technologies make changes in the main subject field of their activities, the processes of creating, storing, and information disseminating. In order to find directions for the transformation of scientific libraries and determine their role in the digital economy, a study of the features of digital transformation and the experience of the digital transformation of foreign libraries was conducted. Management of research data, which is implemented through the creation of Current Research Information Systems (CRIS) was found to be one of the most promising areas of the digital transformation of libraries. The problem area of this direction and ways of engaging libraries in it have been also analyzed in the work.

\section{INTRODUCTION}

The transition to a digital economy contributes to the even greater penetration of digital technologies into our lives and the emergence of new conditions of competition and trends in organizations' development. Big Data, machine learning, and artificial intelligence are becoming common tools implemented by the pioneers of digital transformation in their activities. ${ }^{1}$

Significant changes in the main functions of libraries, storage and dissemination of information caused by the development of digital technologies, affect the operational activities of libraries, user and partners' requests to the library, and ways to meet them. In the process of adapting to these changes, the role of libraries in the digital economy is changing.

This study is designed to find current areas of library development and to determine the role of the library in the digital economy. Achieving this goal requires study of the "digital economy" concept and the peculiarities of the digital transformation of organizations in order to better understand the role of the library in it; research on the development of libraries and determine what best fits the new role of the library in the digital economy; identification of obstacles to the development of this area and ways to engage libraries in it.

\section{THE CONCEPT OF THE “DIGITAL ECONOMY”}

The transition to an information society and digital economy will gradually change all industries, and all companies must change accordingly. ${ }^{2}$ Taking advantage of the digital economy is the main driving force of innovation, competitiveness, and economic development of the country. ${ }^{3}$

The transition to a digital economy is not instant but occurs over many years. The topic emerged starting at the end of the twentieth century, but in recent years has experienced rapid growth. In the Web of Science (WoS) citation database, publications with this term in the title began to be published in 1996 (figure 1).

Serhii Zharinov (serhii.zharinov@gmail.com) is Researcher, State Scientific and Technical Library of Ukraine. (C) 2020. 


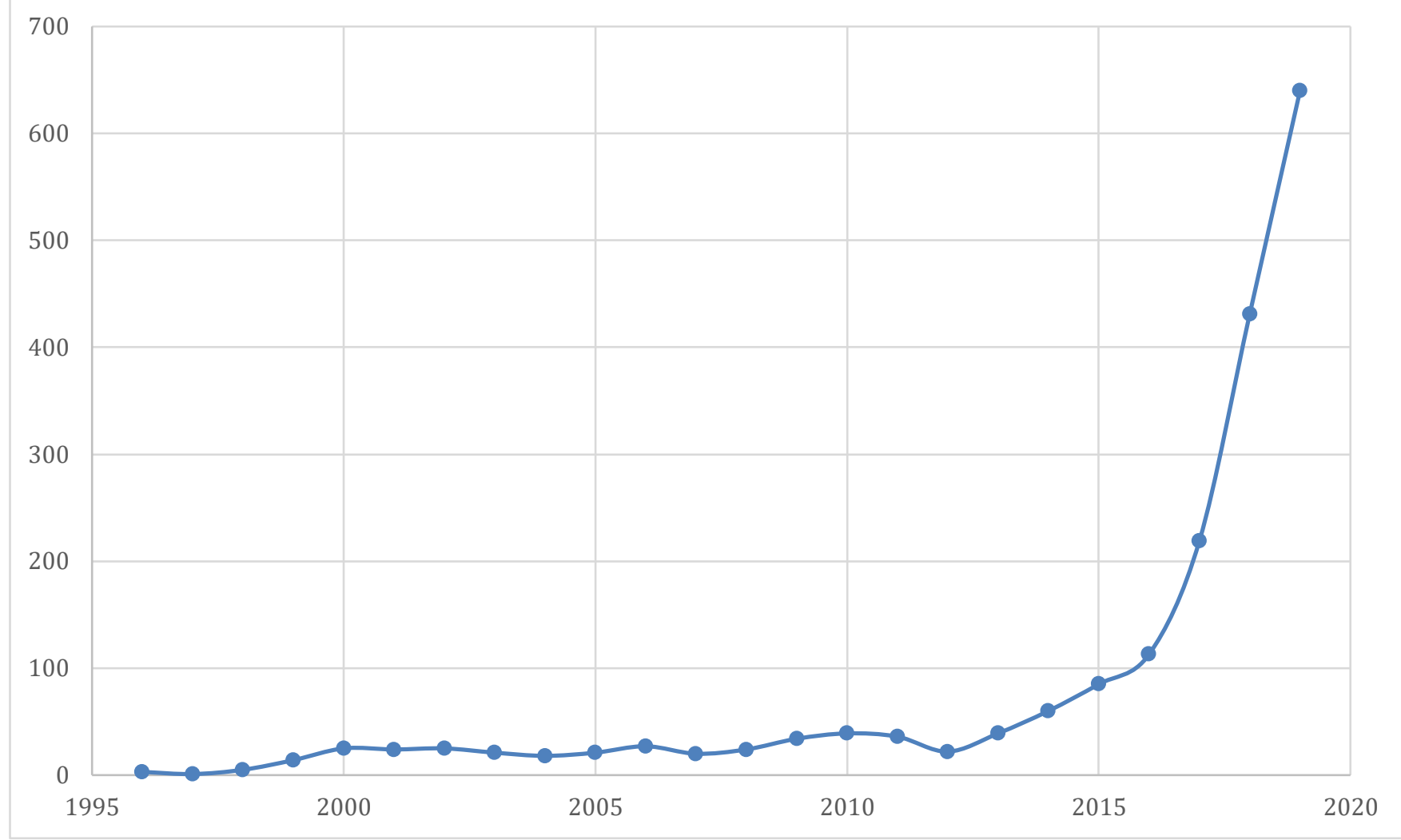

Figure 1. The number of publications in the WoS citation database for the query "digital economy."

One of the first books devoted entirely to the study of the digital economy concept is the work of Don Tapscott, published in 1996. In this book, the author understands the digital economy as an economy in which the use of digital computing technologies in economic activity becomes its dominant component. ${ }^{4}$

Thomas Mesenbourg, an American statistician and economist, identified in 2000 the three main components of the digital economy: e-business, e-commerce, and e-business infrastructure. ${ }^{5} \mathrm{~A}$ number of works on the development of indicators to assess the state of the digital economy, in particular, the work of Philip Barbet and Nathalie Coutinet, are based on the analysis of these components. $^{6}$

Alnoor Bhimani, in his 2003 paper, "Digitization and Accounting Change," defined the digital economy as "the digital interrelationships and dependencies between emerging communication and information technologies, data transfers along predefined channels and emerging platforms, and related contingencies within and across institutional and organizational entities."

Bo Carlsson's 2004 article described the digital economy as a dynamic state of the economy characterized by the constant emergence of new activities based on the use of the Internet and new forms of communication between different authors of ideas, whose communication allows them to generate new activities. ${ }^{8}$

In 2009, John Hand gave the meaning of the digital economy as the new design or use of information and communication technologies that help transform the lives of people, society, or business. ${ }^{9}$ 
Ciocoiu Carmen Nadia, in her 2011 article, explained the digital economy as a state of the economy where knowledge and networking begin to play a more important role than capital in a postindustrial society due to technology. ${ }^{10}$

In a 2014 article, Kit Lesya defined the digital economy as an element of the network economy, characterized by the transformation of all spheres of the economy by transferring information resources and knowledge to a computer platform for further use. ${ }^{11}$

Ukrainian scientists Mykhailo Voinarenko and Larysa Skorobohata, in a study of network tools in 2015, gave the following definition of the digital economy: "The digital economy, unlike the Internet economy, assumes that all economic processes (except for the production of goods) take place independently of the real world. Goods and services do not have a physical medium but are 'electronic.'”12

Yurii Pivovarov, director of the Ukrainian Association for Innovation Development (UAID), gives the following definition: "Digital economy is any activity related to information technology. And in this case, it is important to separate the terms: digital economy and IT sphere. After all, it is not about the development of IT companies, but about the consumption of services or goods they provide-online commerce, e-government, etc.—using digital information technology." 13

Taking into account the above, in this study, the digital economy is defined as digital infrastructure encompasses all business entities and their activities. The transition to the digital economy is the process of creating conditions for the digital transformation of organizations, the creation of digital infrastructure, and the process of gradual involvement of various economic entities and certain sectors of the economy in the digital infrastructure.

One of the first practical and political manifestations of the transition to the digital economy was the European Commission's Index of Digital Economy and Society (DESI), first published in 2014. The main components of the index are communications, human capital, Internet use, digital integration, and digital public services. Among European countries in 2019, there is significant progress in the digitalization of business and in the interaction of society with the state. ${ }^{14}$

For Ukraine, the first step towards the digital economy was the Digital Economy and Development Concept of Ukraine, which defines the understanding of the digital economy, the direction and principles of transition to it. ${ }^{15}$ Thus, for active representatives of the public sector, this concept is a signal that the development of structures and organizations should be based not on improving operational efficiency, but on transformation in accordance with the requirements of Industry 4.0. Confirmation of the seriousness of the Ukrainian government's intentions in this direction is the creation of the Ministry of Digital Transformation in 2019 and the digitization of the latest public services through online services. ${ }^{16}$

One of the priority challenges which needs to be solved at the stage of transition to the digital economy is the development of skills in working with digital technologies in the entire population. This is relevant not only for Ukraine, but also for the European Union. In Europe, a third of the active workforce does not have basic skills in working with digital technologies; in Ukraine, 15.1 percent of Ukrainians do not have digital skills, and the share of the working population with below-average digital skills is 37.9 percent. ${ }^{17}$ 
Part of the solution to this challenge in Ukraine is entrusted to the "Digital Education" project, implemented by the Ministry of Digital Transformation (osvita.diia.gov.ua), which through the mini-series created by him for different target audiences should form digital literacy in the population of Ukraine.

\section{FEATURES OF DIGITAL TRANSFORMATION}

Developed digital skills in the population make the digital transformation of organizations not just a competitive advantage, but a prerequisite for their survival. Thus, the larger the target audience is accustomed to the benefits of the digital economy, the more actively the organization is to adapt to new requirements and customer needs, to the new competitive environment.

Digital transformation of the organization is a complex process that is not limited to the implementation of software in the company's activities or automation of certain components of production. It includes changes to all elements of the company, including methods of manufacturing and customer service, the organization's strategy and business model, approaches, and management methods. According to a study by McKinsey, the integration of new technologies into a company's operations can reduce profits in 45 percent of cases. ${ }^{18}$ Therefore, it is extremely important to have a comprehensive approach to digital transformation, understanding the changes being implemented, choosing the method of their implementation, and gradually involving all structural units and business processes in the process of transformation.

The Boston Consulting Group study identified six factors necessary for the effective use of the benefits of modern technologies: ${ }^{19}$

- connectivity of analytical data;

- integration of technologies and automation;

- analysis of results and application of conclusions;

- strategic partnership;

- competent specialists in all departments; and

- flexible structure and culture.

McKinsey consultants draw attention to the low percentage of successful digital transformation practices and based on the successful experience of 83 companies form five categories of recommendations that can contribute to successful digitalization: ${ }^{20}$

- involvement of leaders experienced in digitalization;

- development of digital staff skills;

- creating conditions for the use of digital skills by staff;

- digitization of tools and working procedures of the company; and

- establishing digital communication and ensuring the availability of information.

Experts at the Institute of Digital Transformation identify four main stages of digital transformation in the company: ${ }^{21}$

1. Research, analysis and understanding of customer experience.

2. Involvement of the team in the process of digital transformation and implementation of corporate culture, which contributes to this process.

3. Building an effective operating model based on modern systems.

4. Transformation of the business model of the organization. 
The "Integrated Model of Digital Transformation" study identifies one of the key factors of successful digital transformation, focusing on priority digital projects, the development and implementation of which should be engaged in specific organizational teams. The authors identify three main functional activities for digital transformation teams, the implementation of which provides a gradual comprehensive renewal of the company, namely: the creation and implementation of digital strategy, digital activity management, digitization of operational activities. $^{22}$

In their study, Ukrainian scientists Natalia Kraus, Oleksandr Holoborodko, and Kateryna Kraus determine that the general pattern for all digital economy projects is their focus on a specific consumer and comprehensive use of available information about the latter and the conditions of project effectiveness. ${ }^{23}$ Initially, the project is pre-tested on a small scale, and only after obtaining satisfactory results from the testing of new principles of activity in a narrow target audience is the project scaled to a wider range of potential users. All this reduces the risks associated with digital transformation. Eliminating unnecessary changes and false hypotheses on a small scale allows to avoid overspending at the stage of a comprehensive transformation of the entire enterprise.

Therefore, the process of effective digital transformation should begin with the involvement of experienced leaders in the field of digital transformation, analysis of the weaknesses of the organization, and building of a plan for its comprehensive transformation, which is divided into individual projects implemented by individual qualified teams with a gradual increase in the volume of these projects, while confirming their effectiveness on a small scale. The process of digital transformation should be accompanied by constant training of employees in digital skills. The goal of digital transformation is to build an efficient, high-profile company that can quickly adapt to new environmental conditions, which is achieved through the introduction of digital technologies and new methods and tools of organization management.

\section{DIRECTIONS OF LIBRARY DEVELOPMENT IN THE DIGITAL ECONOMY}

Based on the study of the digital economy concept and the peculiarities of digital transformation, the review of library development in the digital economy was conducted to find the library's place in digital infrastructure and potential projects that can be implemented on a separate library as part of its comprehensive transformation plan. The main task is to determine the new role of the library in the digital economy and the areas that best meet it.

The search for directions in the development of the library in response to the spread of digital technology began at the end of the last century. One of the first concepts to reflect the impact of the internet on the library sector is the concept of the digital library, published in $1999 .{ }^{24}$ In 2006, the concept of "library 2.0" emerged, which is based on the use of WEB 2.0 technologies, dynamic sites, users become data authors, open-source software, API interfaces, data added to one database is immediately fed to partner databases. ${ }^{25}$ The spread of the use of social networks, mobile technologies, and their successful use in library practice has led to the formation of the concept of "library 3.0." ${ }^{\text {"6 }}$ The development of Open Source, Cloud Service, Big Data, Augmented Reality, Context-Aware, and other technologies has influenced library activities, which is reflected in the "library 4.0."27 Researchers, scholars, and the professional community continued to develop the concepts of the modern library, drawing on the experience of implementing changes in library activities and taking into account the development of other areas, and in 2020 articles began to appear which described the concept of "library 5.0," based on a personalized approach to students, 
support of each student during the whole period of study, development of skills necessary for learning and a set of other supporting actions integrated into the educational process. ${ }^{28}$

In determining the current role of the library in the digital economy, it is necessary to pay attention to a study by Denis Solovianenko, who in identifies research and educational infrastructure as one of the key elements of scientific libraries of the twenty-first century. ${ }^{29}$ Olga Stepanenko considers libraries as part of the information and communication infrastructure, the development of which is one of the main tasks of the transformation of the socioeconomic environment in accordance with the needs of the digital economy, which ensures high efficiency of stakeholders the pace of digitalization of the state economy, which occurs through the development of its constituent elements. ${ }^{30}$ The importance of traditional library services replacing digital infrastructure, based on the example of the Moravian Library, is proved in a study by Michal Indrak and Lenka Pokorna, published in April 2020.31

Projects that contribute to the library's adaptation to the conditions of the digital economy, implemented in the environment of public libraries, include: digitization of library collections (including historical heritage) and the creation of a database of full-text documents; providing free access to the Internet via library computers and Wi-Fi; organization of online customer service, development of services that do not require a physical presence in the library; organization of events for the development of digital skills of users, work with information. ${ }^{32}$ Under such conditions, the role of the librarian as a specialist in the field of information changes from being a custodian to being an intermediary, a distributor. ${ }^{33}$ One of the main objectives of library activity in the digital economy becomes overcoming a digital divide, dissemination of knowledge about modern technologies and innovations, the assistance of their use by the community, development of digital skills in all users of the library. ${ }^{34}$

An example of the digital public library is the Digital North Library project in Canada, which resulted in the creation of the Inuvialuit Digital Library (https://inuvialuitdigitallibrary.ca). The project lasted four years, bringing together researchers from different universities and the community in the region, who together digitized cultural heritage documents and created metadata. The library now has more than 5,200 digital resources collected in 49 catalogues. The implementation of this project provides access to library services and information to a significant number of people living in remote areas of Northern Canada and unable to visit libraries (https://sites.google.com/ualberta.ca/dln/home?authuser=0, https://inuvialuitdigitallibrary.ca). ${ }^{35}$

Other representatives of modern digital libraries, one of the main tasks of which is the preservation of cultural heritage and the spread of national culture, are the British Library (https://www.bl.uk), the Hispanic Digital Library-Biblioteca Nacional de España (http://www.bne.es), Gallica Digital Library in France (https://gallica.bnf.fr), the German Digital Library-Deutsche Digitale Bibliothek (https://www.deutsche-digitale-bibliothek.de), and the European Library (https://www.europeana.eu).

Another direction was the development of analytical skills in information retrieval. Academic libraries, operating with their competencies in information retrieval and information technology, which refined the results of the analysis were able to better identify trends in academia and expand cooperation with teachers to update their curricula. ${ }^{36}$ Libraries become active participants 
in the process of teaching, learning, and assessment of acquired knowledge in educational institutions.

T. 0. Kolesnikova, in her research of models of library development, substantiates the expediency of creating information intelligence centers for the implementation of the latest scientific advances in training and production processes, the involvement of libraries in the activities of higher educational establishments in the educational process, and the creation of centralized repositories as directions of development for university libraries of Ukraine. ${ }^{37}$ One of the advantages of the development and dissemination of digital technologies is the possibility of forming individual curricula for students. Involvement of university libraries in this area is one of the new areas of their activities in the digital economy. ${ }^{38}$

One of the important areas of operation for departmental and scientific-technical libraries that contribute to increasing the innovative potential of the country is activity in the area of intellectual property. Consulting services in the field of intellectual property, information support for scientists, creation of electronic patent information databases in the public domain, and other related services are important components of libraries in many countries. Consulting services in the field of intellectual property, information support for scientists, creation of electronic patentinformation databases in the public domain and other related services are important components of libraries in many countries. ${ }^{39}$ Another important component of libraries' transformation is the deepening of their role in scientific communication; expanding the boundaries of the use of information technology in order to integrate scientific information into a single network; creation and management of information technology infrastructure of science. ${ }^{40}$

The presence of libraries on social networks has become an important component of their digital transformation. On the one hand, libraries have thus created another source of information dissemination and expanded the number of service delivery channels, for the implementation of which they have developed online training videos and interactive help services. ${ }^{41}$ On the other hand, social networks have become a marketing tool to engage the audience in the digital fund of the library and its online services. An additional important component of the presence of libraries in social networks was the establishment of contacts and exchange of ideas with other professional organizations, which contributed to the further expansion of the network of library partners. $^{42}$

Another area of activity that libraries take on in the digital economy is the management of research data, which is confirmed by the significant number of publications on this topic in professional scientific and research journals for $2017-18 .{ }^{43}$ Joining this area allows libraries to become part of the scientific digital information and communication infrastructure, the creation of which is one of the main tasks of digital transformation on the way to the digital economy. ${ }^{44}$ The development of this area contributes to the digitalization of scientific and information sphere, systematization and structuring of all scientific research data has a positive effect on the effectiveness of research, the level of scientific novelty of the results of intellectual activity.

The Ukrainian Institute of the Future with the Digital Agency of Ukraine consider digital transformation as the integration of modern digital technologies into all spheres of business. The introduction of modern technologies (Artificial Intelligence, Blockchain, Koboty, Digital Twins, IIoT Platforms and others) in the production process will lead to the transition to Industry 4.0. According to their forecasts, the key competence in Industry 4.0 should be data processing and 
analytics. ${ }^{45}$ Research information is an integral part of this competence, so the development of this area is one of the most promising for the library in the digital economy. The tools used in the management of research data are called Current Research Information Systems, abbreviated as CRIS. In Ukraine, there is no such system connected to the international community. ${ }^{46}$

The change of the library's role from a repository to its manager, the alignment of the functions and tasks of a CRIS with the key requirements of the digital economy, and the advantages of such systems, together with the fact that they are still not used in Ukraine, make this area extremely relevant for research and a promising area of work of scientific libraries, so we'll consider it more thoroughly.

\section{PROBLEMS IN RESEARCH DATA MANAGEMENT}

The global experience of research information management shows several problems in the process of research data management. Some of them are related to the processes of workflow organization, control, and reporting. This is due to the use of several poorly coordinated systems to organize the work of scientists. Data sets from different systems without metadata are very difficult to combine into a single system, and it is almost impossible to automate the process.

All this is manifested in the lack of information security of the decision-making process in the field of science, both at the state level and at the level of individual structures. This situation can lead to wrong management decisions and can lead to overspending on similar, duplicate projects; increasing the cost of the process of recruiting and finding scientists with relevant experience for research, finding the equipment needed for research.

CRIS, which began to appear in Europe in the 1990s, are designed to overcome these shortcomings and promote the effective organization of scientific work. Such systems are now widespread throughout the world, with a total of about five hundred, which are mainly concentrated in Europe and India. However, there is currently no research information management system in Ukraine that meets international standards and integrates with international scientific databases.

This omission slows down Ukraine's integration into the international scientific community. The solution to this problem may be the creation of the National Electronic Scientific Information System URIS (Ukrainian Research Information System). ${ }^{47}$ The development of this system is an initiative of the Ministry of Education and Science of Ukraine. It is based on combining data from Ukrainian scientific institutions with data from CrossRef and other organizations, as well as ensuring integration with other international CRIS systems through the use of the CERIF standard. Future developers of the system face a number of challenges, both specific and already studied by foreign scientists. A significant number of studies in this area are designed to overcome the problem of lack of access to research data, as well as to solve problems of data standardization and openness.

In the global experience, the directions of collection processes management and development of structured data sets, their distribution on a commercial basis, and also ways of receiving the advantage of providing them in open access are investigated. The mechanisms of financing these processes are studied, in particular, the effective ways of attracting patronage funds are analyzed. The possibilities of licensing the received data sets and their distribution, approaches and tools that can be the most effective for the library are determined. In particular, Alice Wise describes 
the experience of settling some legal aspects by clarifying the use of the site in the license agreement, which covers the conditions of access to information and search in it, while maintaining a certain level of anonymity. ${ }^{48}$

The problem of data consistency is related to the lack of uniform standards for information retention, which would relate to the format of the data, the metadata itself, the methods of their generation and use. Thus, the use of different standards and formats in repositories and archives leads to problems with data consistency in researchers, which, in turn, affects the quality of service delivery and makes it impossible to use multiple data sets. ${ }^{49}$

Another important problem for the dissemination of research data is the lack of tools, components in libraries, and repositories of higher educational establishments and scientific institutions. It is worth to develop the infrastructure so that at the end of the projects, in addition to the research results, the scientists publish the research data they used and generated. This approach will be convenient both for authors (in case they need to reuse the research data) and for other scientists (because they will have access to data that can be used in their own research). ${ }^{50}$ The development of the necessary tools is quite relevant, especially because researcher-practitioners are in favor of sharing the data they create with other researchers and the licensed use of other people's datasets in conducting their own research, according to international surveys. ${ }^{51}$ Another reason for the low prevalence of research data is that datasets have less of an impact on a researcher's reputation and rating than publications. ${ }^{52}$ This is partly due to the lack of citation tracking infrastructure in datasets, in contrast to the publication of research results, and the lack of standards for storing and publishing data.

Prestigious scientific journals have been struggling with this problem for several years. For example, the American Economic Review requires authors whose articles contain empirical work, modelling, or experimental work to provide information about research data in a volume enough for replication. ${ }^{53}$ Nature and Science require authors to preserve research data and provide them at the request of the editors of the journals. ${ }^{54}$

One of the reasons for the underdeveloped infrastructure in research data management is the weak policy of disseminating free access to this data, as a result of which even a small part of usable scientific data remains closed by license agreements and cannot be used by other scientists. ${ }^{55}$ Open science initiatives related to publications have been operating in the scientific field for a long time, but their dissemination to research data remains insufficient.

The development of the URIS system will provide management of scientific information, will solve problems highlighted in the above scientific works of researchers; will promote the efficient use of funds, will simplify the process of finding data for conducting research; will discipline research, and therefore will have a positive impact on the entire economy of Ukraine.

\section{LIBRARY AND RESEARCH INFORMATION MANAGEMENT}

Library involvement in the development process for scientific information management systems will be an important future direction of their work. Such systems, which could include all the necessary information about scientific research, will contribute to the renewal and development of the library sphere of Ukraine, will promote the transition of the state to a digital economy. 
The creation of the URIS system is designed to provide access to research data generated by both Ukrainian and foreign scientists. Such a system can ensure the development of cooperation in the field of research, intensification of knowledge exchange, and interaction through the open exchange of scientific data and integration of Ukrainian scientific infrastructure into the world scientific and information space.

According to surveys conducted by the international organizations EuroCRIS and OCLC, of the 172 respondents working in the field of research information management, 83 percent said that libraries play an important role in the development of open science, copyright, and the deposit of research results. The share of libraries that play a major role in this direction was 90 percent. Almost 68 percent of respondents noted the significant contribution of libraries in filling in the metadata needed to correctly identify the work of researchers in various databases; 60 percent noted the important role of libraries in verifying the correctness of metadata filling by researchers, and almost 49 percent of respondents assess the role of libraries as the main one in the management of research data (figure 4).

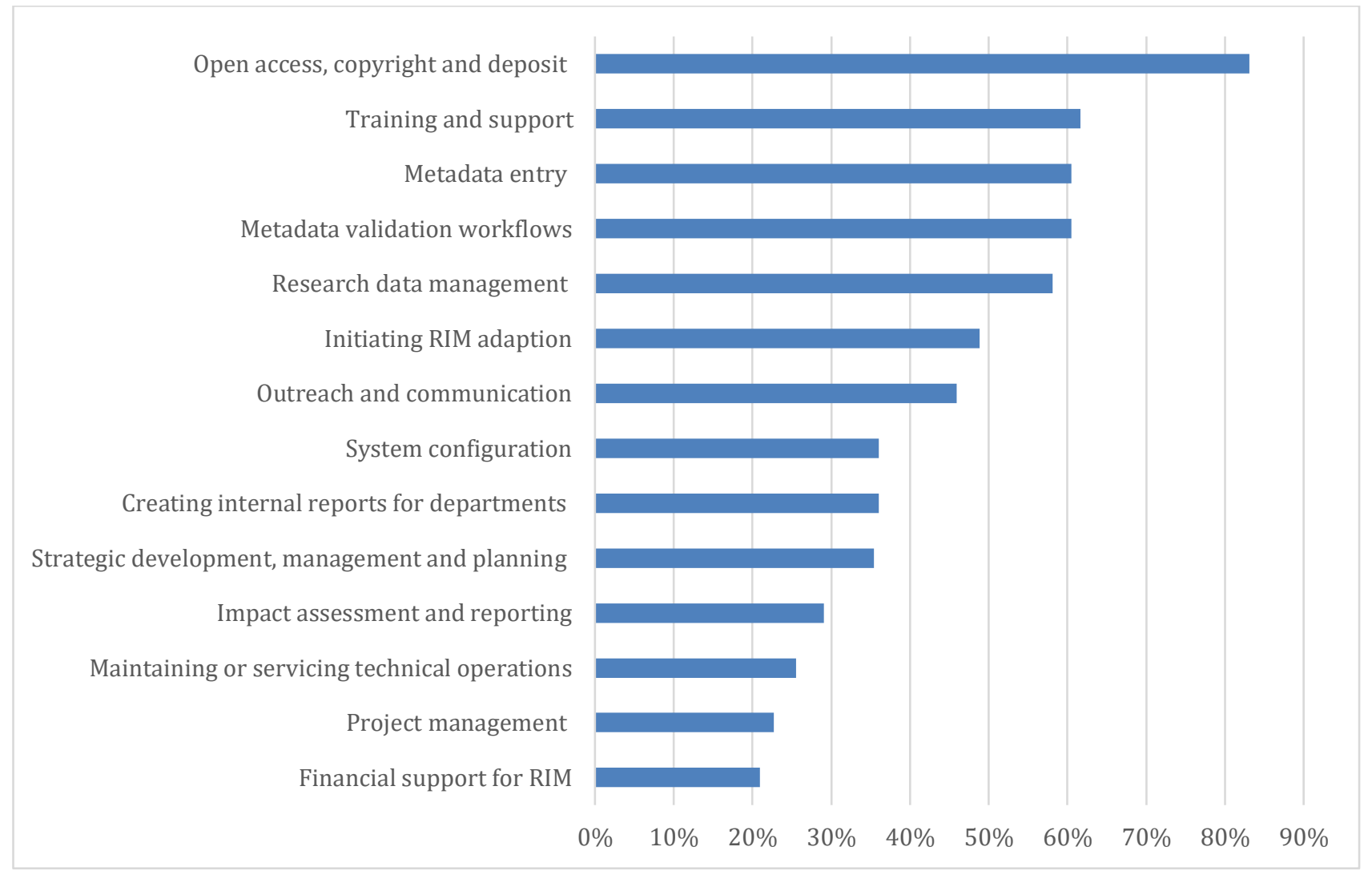

Figure 4. The proportion of organizations among 172 users of CRIS-systems that assess the role of libraries in the management of research information as basic or supporting. ${ }^{56}$

At the same time, the activity of libraries in the direction of assistance in information management of scientific research can take various forms, which should be adopted by scientific libraries of Ukraine; some of these forms will be useful to public libraries that can become science ambassadors in their communities. Based on the experience of foreign libraries, we have identified areas of activity in which the library can join the management of research information. 
One of the main directions for libraries that cooperate with CRIS users or are themselves the organizers of such systems is the introduction and support of open science. Historically, libraries support open science because they provide access to scientific papers, but they can further expand their activities. Using open data resources and promoting them among the scientific community, involving scientific users in disseminating their own research results on the principles of open science, supporting users in disseminating their publications, creating conditions for increasing the citation of scientific papers, tracking information about user publications, creating and support of public profiles of scientists in scientific and professional resources and scientific social networks-all this will help to intensify researchers in engaging in open science and take advantages of this area.

The analysis of the world experience shows that in the activity of scientific libraries there is a significant intensification of support for the strategic goals of the structures that finance their activities and to which they are subordinated. Libraries are moving away from the usual customer service and expanding their activities through the use of their own assets and the introduction of new modern tools. Such libraries try to promote the development of parent structures, increase modern competencies to meet the needs and goals of these institutions better. By introducing and implementing various tools for the development of management, libraries synchronize their strategy with the strategy of the parent structure to achieve a synergistic effect.

The next important direction of library development is their socialization. Wanting to get rid of the antiquated understanding of the word library, many of them conduct campaigns aimed at changing the image of the library in the imagination of users, communities, and society. An important component of this system step is to build relationships with the target audience, creating user communities around the library, which are not only its users but also supporters, friends, and promoters. Building relationships with members of the scientific community allows libraries to reduce resistance to change as a result of the introduction of scientific information management systems; to influence users positively so that they introduce new tools into their usual activities, receive benefits, and become an active part of the scientific space structuring process.

Recently, work with metadata has undergone some changes. The need for identification and structuring of data in the world scientific space leads to the fact that they are already filled not only by libraries but also by other organizations that produce, issued, publish scientific results and scientific literature. Scientists are beginning to make more active use of modern standards in the field of information in order to promote their own work. Libraries, in turn, take on the role of consultant or contractor with many years of experience working with metadata and sufficient knowledge in this area. On the other hand, filling in metadata by users frees up the time of librarians and creates conditions for them to perform other functions, such as information management, creation of automated data collection and management systems integrated with scientific databases-both Ukrainian and international.

Another area of research information management is the direct management of this process. Thus, CRIS are developed and implemented with the contribution of scientific libraries in different countries of the world. This allows libraries to combine disparate data obtained from different sources, compile scientific reports, evaluate the effectiveness of scientific activities of the institution, create profiles of scientific institutions and scientists, develop research networks, etc. 
Scientists and students can find the results of scientific research, and look for partners and sources of funding for research. Research managers have access to up-to-date scientific information, which allows to more accurately assess the productivity and influence of individual scientists, research groups and institutions. Business representatives get access to up-to-date information on promising scientific developments, and the public - a way to control research conducting effectively.

\section{CONCLUSIONS}

Ukraine is on the path to a digital economy, characterized by the penetration of new technologies in all areas of human activity, simplification of access to information, goods and services, blurring the geographical boundaries of companies, increasing the share of automated and robotic production units, strengthening the role of creation and use databases. These changes affect all sectors of the economy, and all organizations, without exception, need to adapt accordingly. Rapid response to relevant changes helps to increase competitiveness both at the level of individual organizations and at the level of the state economy.

Adaptation to the conditions of the digital economy occurs through digital transformation $-\mathrm{a}$ complex process that requires a review of all business processes of the organization and radically changes its business model. The digital transformation of the organization takes place through the involvement of management, which is competent in digitization, updating management methods, developing digital skills, establishing efficient production and services, implementing digital to ols and building digital communication, implementing individual development projects, and adapting to new user needs.

The digital transformation of the economy occurs through the transformation of its individual sectors, creating conditions for the transformation of their representatives. One of the first steps in the process of transition to the digital economy is the establishment of digital information and communication infrastructure. Libraries are representatives of the information sphere, which were the main operators of information in the analogue era. Significant changes in the subject area of their activities require the search for a new role for libraries.

Modern projects and directions of library development are integral elements of transformation to the conditions of the digital economy. The result of completing this complex implementation will allow libraries to update their management methods, the range of services, and the channels of their provision; change fixed assets through their digitization, structuring the data and creating metadata; affect approaches to communication with users and cooperation with both domestic and international partners; change the functions and positioning of the library; and will enable them become effective information operator-managers.

In the digital economy, the role of the library is changing from passively collecting and storing information to actively managing it. One of the areas of development that most comprehensively meets this role is the management of research data, which is implemented through the creation of CRIS systems. Thus, the main asset of libraries is a digital, structured database, which is automatically and regularly updated, the main focus of which is to support the decision-making process. The library becomes an assistant in conducting research, finding funding, partners, fixed assets and information; a partner in the strategic management of both scientific organizations and the state at the level of committees and ministries. 
The development of this area in Ukraine requires solving a number of technical, administrative, and managerial questions that are relevant not only in Ukraine, but also around the world. In particular, libraries need to address the issue of data integration and consistency, its accessibility and openness, copyright, and personal data issues. Solving the problems of creation and operation of CRIS systems in Ukraine are promising areas for future research.

\section{ENDNOTES}

${ }^{1}$ Andriy Dobrynin, Konstantin Chernykh, Vasyl Kupriyanovsky, Pavlo Kupriyanovsky and Serhiy Sinyagov, "Tsifrovaya ekonomika-razlichnyie puti k effektivnomu primeneniyu tehnologiy (BIM, PLM, CAD, IOT, Smart City, BIG DATA i drugie)," International Journal of Open Information Technologies 4, no. 1 (2016): 4-10, https://cyberleninka.ru/article/n/tsifrovayaekonomika-razlichnye-puti-k-effektivnomu-primeneniyu-tehnologiy-bim-plm-cad-iot-smartcity-big-data-i-drugie.

${ }^{2}$ Jurgen Meffert, Volodymyr Kulagin, and Alexander Suharevskiy, Digital @ Scale: nastolnaya kniga po tsifrovizatsii biznesa (Moscow: Alpina, 2019).

${ }^{3}$ Victoria Apalkova, "Kontseptsiia rozvytku tsyfrovoi ekonomiky v Yevrosoiuzi ta perspektyvy Ukrainy," Visnyk Dnipropetrovskoho universytetu. Seriia «Menedzhment innovatsii» 23, no. 4 (2015): 9-18, http://nbuv.gov.ua/UJRN/vdumi 20152344.

${ }^{4}$ Don Tapscott, The Digital Economy: Promise and Peril in the Age of Networked Intelligence (New York: McGraw-Hill, 1996).

5 Thomas L. Mesenbourg, Measuring the Digital Economy (Washington, DC: Bureau of the Census, 2001).

${ }^{6}$ Philippe Barbet and Nathalie Coutinet, "Measuring the Digital Economy: State-of-the-Art Developments and Future Prospects," Communications \& Strategies, no. 42 (2001): 153, http://citeseerx.ist.psu.edu/viewdoc/download?doi=10.1.1.576.1856\&rep=rep1\&type=pdf.

${ }^{7}$ Alnoor Bhimani, “Digitization and Accounting Change," in Management Accounting in the Digital Economy, edited by Alnoor Bhimani, 1-12 (London: Oxford University Press, 2003), https://doi.org/10.1093/0199260389.003.0001.

${ }^{8}$ Bo Carlsson, "The Digital Economy: What is $\mathrm{M}=\mathrm{New}$ and What is Not?," Structural Change and Economic Dynamics 15, no. 3 (September 2004): 245-64, https://doi.org/10.1016/j.strueco.2004.02.001.

9 John Hand, "Building Digital Economy—The Research Councils Programme and the Vision," Lecture Notes of the Institute for Computer Sciences, Social Informatics and Telecommunications Engineering 16, (2009): 3, https://doi.org/10.1007/978-3-642-11284-3 1.

${ }^{10}$ Carmen Nadia Ciocoiu, "Integration Digital Economy and Green Economy: Opportunities for Sustainable Development," Theoretical and Empirical Researches in Urban Management 6, no. 1 (2011): 33-43, https://www.researchgate.net/publication/227346561. 
${ }^{11}$ Lesya Zenoviivna Kit, “Evoliutsiia Merezhevoi Ekonomiky,” Visnyk Khmelnytskoho Natsionalnoho Universytetu, Ekonomichni nauky, no. 3 (2014): 187-94, http://nbuv.gov.ua/UJRN/Vchnu ekon 2014 3\%282\%29 42.

12 Mykhailo Voinarenko and Larissa Skorobohata, "Merezhevi Instrumenty Kapitalizatsii Informatsiino-intelektualnoho Potentsialu ta Innovatsii," Visnyk Khmelnytskoho Natsionalnoho Universytetu, . Ekonomichni nauky, no. 3 (2015): 18-24, http://elar.khnu.km.ua/jspui/handle/123456789/4259.

${ }^{13}$ Yurii Pivovarov, “Ukraina Perehodut na “Cifrovu Economic," Sccho ce oznachae,” edited by Miroslav Liskovuch. Ukrinform (January 21, 2020). https://www.ukrinform.ua/rubricsociety/2385945-ukraina-perehodit-na-cifrovu-ekonomiku-so-ce-oznacae.html.

${ }^{14}$ European Commission, "Digital Economy and Society Index," Brussels, Belgium, https://ec.europa.eu/commission/news/digital-economy-and-society-index-2019-jun-11 en.

${ }^{15}$ Kabinet Ministriv Ukrainu, "Pro Skhvalennia Kontseptsii Rozvytku Tsyfrovoi Ekonomiky ta Suspilstva Ukrainy na 2018-2020 Roky ta Zatverdzhennia Planu Zakhodiv Shchodo yii Realizatsii," (Kyiv: 2018), https://zakon.rada.gov.ua/laws/show/67-2018-\%D1\%80.

${ }^{16}$ Kabinet Ministriv Ukrainu, “Pytannia Ministerstva Tsyfrovoi Transformatsii,” (Kyiv: 2019), https://zakon.rada.gov.ua/laws/show/856-2019-\%D0\%BF.

17 Piatuy, "Biblioteky Stanut Pershymy Oflain-khabamy: Mintsyfry Zapustyt Kursy z Tsyfrovoi Osvity," https://www.5.ua/suspilstvo/biblioteky-stanut-pershymy-oflain-khabamy-mintsyfryzapustyt-kursy-z-tsyfrovoi-osvity-206206.html.

18 Jacques Bughin, Jonathan Deaki, and Barbara O’Beirne, “Digital Transformation: Improving the Odds of Success," McKinsey \& Company, https://www.mckinsey.com/businessfunctions/mckinsey-digital/our-insights/digital-transformation-improving-the-odds-ofsuccess.

${ }^{19}$ Domynyk Fyld, Shylpa Patel, and Henry Leon, "Kak Dostich Tsifrovoy Zrelosti," The Boston Consulting Group Inc. (2018), https://www.thinkwithgoogle.com/ qs/documents/5685/ru AdWords Marketing Sales 89 1609 Mastering Digital Marketing Maturity.pdf.

${ }^{20}$ Hortense de la Boutetière, Alberto Montagner, and Angelika Reich, "Unlocking Success in Digital Transformations," McKinsey \& Company, https://www.mckinsey.com/businessfunctions/organization/our-insights/unlocking-success-in-digital-transformations.

21 Top Lea, “Tsyfrova Transformatsiia Biznesu: Navishcho vona Potribna i Shche 14 Pytan," BusinessViews, https://businessviews.com.ua/ru/business/id/cifrova-transformacijabiznesu-navischo-vona-potribna-i-sche-14-pitan-2046.

22 Vasily Kupriyanovsky, Andrey Dobrynin, Sergey Sinyagov, and Dmitry Namiot, "Tselostnaya Model Transformatsii v Tsifrovoy Ekonomike-Kak Stat Tsifrovyimi Liderami," International Journal of Open Information Technologies 5, no. 1 (2017): 26-33, 
https://cyberleninka.ru/article/n/tselostnaya-model-transformatsii-v-tsifrovoy-ekonomikekak-stat-tsifrovymi-liderami.

${ }^{23}$ Nataliia Kraus, Alexander Holoborodko, and Kateryna Kraus, "Tsyfrova Ekonomika: Trendy ta Perspektyvy Avanhardnoho Kharakteru Rozvytku," Efektyvna Ekonomika no. 1 (2018): 1-7, http://www.economy.nayka.com.ua/pdf/1 2018/8.pdf.

${ }^{24}$ David Bawden and Ian Rowlands, "Digital Libraries: Assumptions and Concepts," International Journal of Libraries and Information Studies (Libri), no. 49 (1999): 181-91, https://doi.org/10.1515/libr.1999.49.4.181.

25 Jack M. Maness, "Library 2.0: The Next Generation of Web-based Library Services," LOGOS 13, no. 3 (2006): 139-45, https://doi.org/10.2959/logo.2006.17.3.139.

${ }^{26}$ Woody Evans, Building Library 3.0: Issues in Creating a Culture of Participation (Oxford: Chandos Publishing, 2009).

${ }^{27}$ Younghee Noh, "Imagining Library 4.0: Creating a Model for Future Libraries," The Journal of Academic Librarianship 41, no. 6 (November 2015): 786-97, https://doi.org/10.1016/i.acalib.2015.08.020.

${ }^{28}$ Helle Guldberg et al., "Library 5.0," Septentrio Conference Series, UiT The Arctic University of Norway, no. 3 (2020), https://doi.org/10.7557/5.5378.

${ }^{29}$ Denys Solovianenko, "Akademichni Biblioteky u Novomu Sotsiotekhnichnomu Vymiri. Chastyna Chetverta. Suchasnyi Riven Dyskursu Akademichnoho Bibliotekoznavstva ta Postup E-nauky," Bibliotechnyi visnyk no.1 (2011): 8-24, http://journals.uran.ua/bv/article/view/2011.1.02.

${ }^{30}$ Olga Petrivna Stepanenko, "Perspektyvni Napriamy Tsyfrovoi Transformatsii v Konteksti Rozbudovy Tsyfrovoi Ekonomiky," in Modeliuvannia ta informatsiini systemy v ekonomitsi : zb. nauk. pr., edited by V. K. Halitsyn, (Kyiv: KNEU, 2017), 120-31, https://ir.kneu.edu.ua/bitstream/handle/2010/23788/120-

131.pdf?sequence $=1$ \&isAllowed $=y$.

${ }^{31}$ Michal Indrák and Lenka Pokorná, "Analysis of Digital Transformation of Services in a Research Library," Global Knowledge, Memory and Communication (2020), https://doi.org/10.1108/GKMC-09-2019-0118.

32 Irina Sergeevna Koroleva, "Biblioteka-Optimalnaya Model Vzaimodeystviya s Polzovatelyami v Usloviyah Tsifrovoy Ekonomiki," Informatsionno-bibliotechnyie sistemyi, resursyi i tehnologii no. 1 (2020): 57-64, https://doi.org/10.20913/2618-7515-2020-1-57-64.

33 James Currall and Michael Moss, "We are Archivists, But are We OK?", Records Management Journal 18, no. 1 (2008): 69-91, https://doi.org/10.1108/09565690810858532.

${ }^{34}$ Kirralie Houghton, Marcus Foth and Evonne Miller, "The Local Library across the Digital and Physical City: Opportunities for Economic Development," Commonwealth Journal of Local Governance no. 15 (2014): 39-60, https://doi.org/10.5130/cjlg.v0i0.4062. 
${ }^{35}$ Sharon Farnel and Ali Shiri, "Community-Driven Knowledge Organization for Cultural Heritage Digital Libraries: The Case of the Inuvialuit Settlement Region," Advances in Classification Research Online no. 1 (2019): 9-12, https://doi.org/10.7152/acro.v29i1.15453.

${ }^{36}$ Elizabeth Tait, Konstantina Martzoukou, and Peter Reid, "Libraries for the Future: The Role of IT Utilities in the Transformation of Academic Libraries," Palgrave Communications no. 2 (2016): 1-9, https://doi.org/10.1057/palcomms.2016.70.

37 Tatiana Alexandrovna Kolesnykova, "Suchasna Biblioteka VNZ: Modeli Rozvytku v Umovakh Informatyzatsii," Bibliotekoznavstvo. Dokumentoznavstvo. Informolohiia no. 4 (2009): 57-62, http://nbuv.gov.ua/UJRN/bdi 2009410.

${ }^{38}$ Ekaterina Kudrina and Karina Ivina, "Digital Environment as a New Challenge for the University Library," Bulletin of Kemerovo State University. Series: humanities and social sciences 2, no. 10 (2019): 126-34, https://doi.org/10.21603/2542-1840-2019-3-2-126-134.

${ }^{39}$ Anna Kochetkova, “Tsyfrovi Biblioteky yak Oznaka XXI Stolittia,” Svitohliad no. 6 (2009): 68-73, https://www.mao.kiev.ua/biblio/jscans/svitogliad/svit-2009-20-6/svit-2009-20-6-68kochetkova.pdf.

40 Victoria Alexandrovna Kopanieva, "Naukova Biblioteka: Vid E-katalohu do E-nauky," Bibliotekoznavstvo. Dokumentoznavstvo. Informolohiia no. 6 (2016): 4-10, http://nbuv.gov.ua/UJRN/bdi 201633.

${ }^{41}$ Christy R. Stevens, "Reference Reviewed and Re-Envisioned: Revamping Librarian and DeskCentric Services with LibStARs and LibAnswers," The Journal of Academic Librarianship 39, no. 2 (March 2013): 202-14, https://doi.org/10.1016/j.acalib.2012.11.006.

42 Samuel Kai-Wah Chu and Helen S Du, "Social Networking Tools for Academic Libraries," Journal of Librarianship and Information Science 45, no. 1 (February 17, 2012): 64-75, https://doi.org/10.1177/0961000611434361.

43 ACRL Research Planning and Review Committee, “2018 Top Trends in Academic Libraries A Review of the Trends and Issues Affecting Academic Libraries in Higher Education," $C \& R L$ News 79, no.6 (2018): 286-300. https://doi.org/10.5860/crln.79.6.286.

${ }^{44}$ Currall and Moss, "We are Archivists, but are We OK?", 69-91, https://doi.org/10.1108/09565690810858532.

${ }^{45}$ Valerii Fishchuk et al., "Ukraina 2030E - Kraina z Rozvynutoiu Tsyfrovoiu Ekonomikoiu,” Ukrainskyi instytut maibutnoho, 2018, https://strategy.uifuture.org/kraina-z-rozvinutoyucifrovoyu-ekonomikoyu.html.

${ }^{46}$ EuroCRIS, "Search the Directory of Research Information System (DRIS)," https://dspacecris.eurocris.org/cris/explore/dris.

${ }^{47}$ MON, “MON Zapustylo Novyi Poshukovyi Servis dlia Naukovtsiv-Vin Bezkoshtovnyi ta Bazuietsia na Vidkrytykh Danykh z Usoho Svituю," https://mon.gov.ua/ua/news/mon- 
zapustilo-novij-poshukovij-servis-dlya-naukovciv-vin-bezkoshtovnij-ta-bazuyetsya-navidkritih-danih-z-usogo-svitu.

${ }^{48}$ Nancy Herther et al., "Text and Data Mining Contracts: The Issues and Needs," Proceedings of the Charleston Library Conference, 2016, https://doi.org/10.5703/1288284316233.

${ }^{49}$ Karen Hogenboom and Michele Hayslett, "Pioneers in the Wild West: Managing Data Collections." Portal: Libraries and the Academy 17, no. 2 (2017): 295-319, https://doi.org/10.1353/pla.2017.0018.

50 Philip Young et al., "Library Support for Text and Data Mining," A Report for the University Libraries at Virginia Tech, 2017, http://bit.ly/2FccOwu.

${ }^{51}$ Carol Tenopir et al., "Data Sharing by Scientists: Practices and Perceptions," PloS One 6 (2011), no. 6, https://doi.org/10.1371/journal.pone.0021101.

${ }^{52}$ Filip Kruse and Jesper Boserup Thestrup, “Research Libraries' New Role in Research Data Management, Current Trends and Visions in Denmark," Liber Quarterly 23, no.4 (2014): 31035, https://doi.org/10.18352/lq.9173.

53 American Economic Review, "Data and Code." AER Guidelines for Accepted Articles. Instructions for Preparation of Accepted Manuscripts, 2020, https://www.aeaweb.org/journals/aer/submissions/accepted-articles/styleguide\#IIC.

54 “Data Access and Retention." The Publication Ethics and Malpractice Statement, (New York: Marsland Press, 2019), http://www.sciencepub.net/marslandfile/ethics.pdf.

55 Patricia Cleary et al., “Text Mining 101: What You Should Know," The Serials Librarian 72, no.1-4 (May 2017): 156-59, https://doi.org/10.1080/0361526X.2017.1320876.

${ }^{56}$ Rebecca Bryant et al., Practices and Patterns in Research Information Management Findings from a Global Survey (Dublin: OCLC Research, 2018), https://doi.org/10.25333/BGFG-D241. 